\title{
Lassa Fever
}

National Cancer Institute

\section{Source}

National Cancer Institute. Lassa Fever. NCI Thesaurus. Code C128418.

A viral hemorrhagic fever that is caused by the Lassa virus, which is transmitted by contact with infected rodents; it is characterized by fever, headache, malaise, myalgia, and hearing loss. 